\title{
Traktori-työkoneautomaation käytettävyys
}

Kim O. Kaustell

MTT Taloustutkimus, Latokartanonkaari 9,00790 Helsinki, kim.kaustell@mtt.fi

\section{Tiivistelmä}

Maatalousyrittäjät pyrkivät tehostamaan tuotantoaan kasvattamalla tilakokoaan ja lisäämällä konekapasiteettiaan. Seuraavana vaiheena tulee työvaiheiden automatisointi. Kustannuksia voidaan alentaa entisestään, jos työ voidaan tehdä mahdollisimman pienellä ihmistyömäärällä ja jos yksi henkilö pystyy käsittelemään mahdollisimman suurta pinta-alaa. Myös tiettyjen, esimerkiksi peltoviljelyyn liittyvien työvaiheiden alihankinta lisääntyy. Samanaikaisesti kiinnitetään yhä enemmän huomiota maatalouden ympäristökysymyksiin.

Käyttöturvallisuus on tärkeä osa konejärjestelmässä etenkin kun on kyse koneista, joissa automaatio ohjaa pääsääntöisesti konetta ja ihmisen rooli järjestelmässä on valvoa työn sujumista ja puuttua tarvittaessa ohjaukseen, esimerkiksi ongelmatilanteissa. Kuljettajan tilannetietoisuuden ylläpitäminen koneen ja ihmisen vuorovaikutuksen osalta tulee tärkeäksi, jolloin käyttöliittymän välittämän informaation sisällön sekä muodon merkitys kasvaa. Automaatio ja työkonejärjestelmiä suunniteltaessa olisi osattava ottaa huomioon kuljettajan ominaisuudet entistä laajemmin, jotta uusista järjestelmistä saatava hyöty olisi mahdollisimman suuri ilman että käyttäjää rasitetaan tarpeettomasti.

ISOBUS-yhteensopivassa traktori-työkoneyhdistelmässä kuljettajalla on käytössä traktorin omat hallinta- ja käyttöliittymälaitteet, työkoneille yhteinen käyttöliittymälaite virtuaaliterminaali (VT) ja tehtäväohjainlaite (TC). VT:n avulla ohjataan eri työkoneiden toimintoja ja TC:n avulla hallitaan maatilan suunnitteluohjelmistolla tehtyä työtehtävää pellolla. Hankkeen ensisijainen tavoite on tuottaa käytettävyyden kriteereitä vahvasti yleistymässä olevien, ISOBUS:iin perustuvien, traktorityökoneautomaation sovellutuksille. Tässä tutkimuksessa erityisenä painopisteenä pidetään em. järjestelmien käyttäjän l. työkoneen kuljettajan ergonomiaa.

Tutkimuksessa käytetään katsekameraa (Gaze Tracking) sekä heuristista analyysiä traktorikylvölannoitin-yhdistelmään liittyvien automaatiokäyttöliittymien käytettävyyden arviointiin. Analysoimalla katseen kohdistumista kuljettajan työn aikana tehdään johtopäätöksiä mm. sitä, ovatko käyttöliittymän dialogi ja logiikka koneyhdistelmän käyttäjän kannalta helppokäyttöisiä ja tehokkaita. Täydennettynä haastattelulla ja asiantuntija-arvioinnilla (heuristinen arviointi) voidaan edelleen tehdä johtopäätöksiä siitä, ovatko käyttöliittymät miellyttäviä. Monikanavavideoinnin avulla saadaan kokonaiskuva kuljettajan aikabudjetista työn aikana.

Tarkastellun järjestelmän toteutuksessa on tähän mennessä havaittu puutteita mm. järjestelmän käyttöliittymälaitteiden sijoittelussa ohjaamoon, käyttöliittymän ymmärrettävyydessä sekä virhetilanteiden ilmaisemisessa ja niistä palautumisessa.

Tarkasteltua ISOBUS-yhteensopivaa järjestelmää testataan ja kehitetään edelleen keväällä 2012. Tämän tuloksena saadaan lisää suunnittelukriteereitä järjestelmän käytettävyydelle turvallisuuden, tehokkuuden ja käytön miellyttävyyden näkökulmasta. Koska ohjaamossa olevat käyttöliittymän osat kuitenkin ovat vain osa tarkasteltavaa järjestelmää, on jatkossa arvioitava koko järjestelmää samoista näkökulmista.

\section{Asiasanat}

Traktori, työkone, automaatio, ISOBUS, käytettävyys, maatalous 


\section{Johdanto}

Järkevän automaation avulla voidaan parantaa suomalaisten maatalouskoneyritysten kilpailukykyä kansainvälisesti. Maatalouskoneteollisuudessa viennin osuus on suurusluokaltaan yli puoli miljardia euroa ja sen merkitys tulee korostumaan lähitulevaisuudessa. MTT:ssä meneillään olevat maataloustyökoneiden automaatiohankkeet pyrkivät tukemaan ja tuottamaan suomalaisille maatalouskonevalmistajille perustietoa ja menetelmiä, jotka tukevat heidän tuotekehitystään. Samalla tuetaan tuotteiden loppukäyttäjiä eli viljelijöitä siten, että heillä on mahdollisuus hankkia uutta teknologiaa kotimaan markkinoilta. Suomen maatalousyrittäjät pyrkivät tehostamaan tuotantoaan kasvattamalla tilakokoaan ja lisäämällä konekapasiteettiaan. Seuraavana vaiheena tulee työvaiheiden automatisointi. Kustannuksia voidaan alentaa entisestään, jos työ voidaan tehdä mahdollisimman pienellä ihmistyömäärällä ja jos yksi henkilö pystyy käsittelemään mahdollisimman suurta pinta-alaa tai eläinmäärää. Samanaikaisesti kiinnitetään yhä enemmän huomiota maatalouden ympäristökysymyksiin ja eläinten hyvinvointiin.

Mekatronisoitumisen myötä sulautetun automaation merkitys kasvaa tulevaisuudessa maatalouskoneiden kilpailutekijänä. Automaation avulla toteutettavien käytettävyysominaisuuksien painoarvo koneiden myyntiargumenttina tulee korostumaan ja kasvamaan. Traktorien ja työkoneiden välisen tiedonsiirron standardointi ISO 11783 (ISOBUS) on osaltaan helpottamassa uusien ohjausratkaisuiden toteutusta ja laajempaa käyttöönottoa. Automaatio ja sen käyttö onkin yleistynyt suomalaisessa maatalouskoneteollisuudessa. Maatalouskoneita kehittävät yritykset ovat viime vuosina panostaneet tuotteiden ohjattavuusominaisuuksiin ja käyttöliittymien parantamiseen. Jotta viljelijän työtä helpottavat automaatiojärjestelmät tulisivat nopeammin käytäntöön, on alan tutkimuksessa kiinnitettävä yhä enemmän huomiota järjestelmien turvallisuuteen ja käytettävyyteen (Kuvio 1). Maatalousteknologian alalla tehty käytettävyystutkimus (Kaustell \& Mattila 2008, Kaustell ym. 2008, Haapala ym. 2007, Nurkka 2006 ja 2005, Nurkka \& Suomi 2006) on osoittanut, että laitteiden testaamisen avulla laitteen käyttöön liittyvät ongelmat ovat löydettävissä.

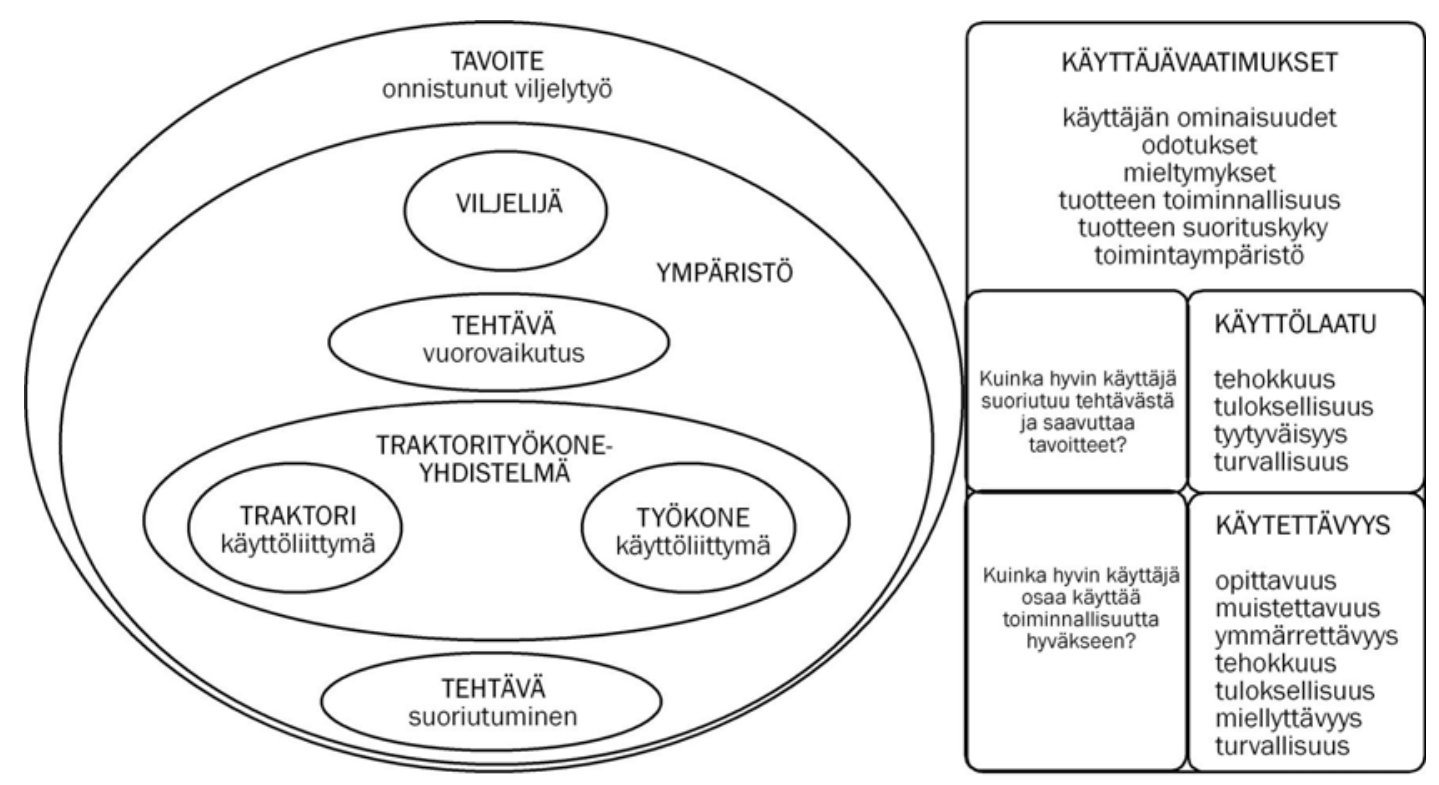

Kuva 1. Maatalouskoneen käytettävyyden viitekehys (Nurkka 2006)

Tämän hankkeen tavoitteena on tuottaa käytettävyyden kriteereitä vahvasti yleistymässä olevien ja ISOBUS:iin perustuvan traktori-työkoneautomaation sovellutuksille. Hankkeen erityisenä painopisteenä ovat em. järjestelmien käyttäjän l. työkoneen kuljettajan ergonomia ja käyttäjäkokemus.

\section{Aineisto ja menetelmät}

Hankkeen aineisto on kirjallisuustutkimuksen ohella hankittu kahdella menetelmällä: asiantuntijaarvioinnilla ja katsekameratutkimuksella. Näitä on täydennetty käyttäjähaastattelulla. Asiantuntija- 
arvioinnissa sovellettiin yleisesti käyttöliittymien arvioinnissa käytettyjä Nielsenin heuristiikkoja (Nielsen 1993) Heuristinen arviointi tehtiin tarkistulistan avulla järjestelmän ollessa asennettuna käyttökuntoon traktorin ohjaamossa.

Katsekameraa ja samanaikaista monikanavavideointia käytettiin järjestelmän todellisessa käyttötilanteessa syyskylvötyön yhteydessä syksyllä 2011. Menetelmän avulla saatiin tallennettua kuljettajan toiminta työn aikana ja erityisesti työn aikana visuaalista huomiota vaatineet kohteet, joista osa liittyy käytettyyn ISOBUS-automaatiojärjestelmään. Myös käyttäjän ajonaikaiset kommentit tallentuivat videolle.

\section{Tulokset ja tulosten tarkastelu}

\section{ISOBUS-järjestelmän käyttöliittymäkomponenttien sijoittelu ohjaamoon}

Kun traktorin ohjaamoon asennetaan käyttöliittymän komponentteja kuten näyttöjä ja näppäimistöjä, on oleellista, että ne voitaisiin sijoittaa käyttäjän ja käyttöturvallisuuden kannalta oikein. Mm. merkinantolaitteiden ja ohjaimien suunnittelun ergonomisia vaatimuksia koskeva standardisarja antaa hyviä ohjeita toimivalle ja turvalliselle sijoittelulle (SFS-EN 894-4 2010). Jälkiasennettavien käyttöliittymäkomponenttien sijoittelussa on ongelmana se, ettei näille välttämättä ole varattu tilaa ohjaamossa. Myös komponentin kiinnitys ja johdotuksen järjestäminen laitteelle voi olla hankalaa. Käytännössä laitteet asennetaan siihen, mihin olemassa olevat rakenteet ja käytettävissä olevat kiinityselimet antavat mahdollisuuden. Käyttäjän kannalta tämä voi johtaa huonoon työasentoon, vaikeuttaa muiden hallintalaitteiden käyttöä ja viedä näytön liian kauas katsojasta. Tällöin näyttöjen tekstit ja symbolit saattavat jäädä liian pieniksi ja esim. visuaalisen palautteen tai hälytysten havaitseminen on vaikeampaa. Virtuaaliterminaalissa ei ole mahdollisuutta skaalata näytöllä olevien elementtien kokoa katseluetäisyyttä vastaavaksi, vaikka tällä voitaisiin hieman kompensoida huonosta asennuspaikasta aiheutuvaa haittaa.

\section{Virtuaaliterminaali-käyttöliittymän muotoilu}

Hyvän käyttöliittymänäytön toteutuksessa on oleellista noudattaa mahdollisimman pitkälle käyttäjälle tutun prosessin suoritusta ja sen analogioita. Keskeistä on myös se, että eri toiminnot ovat helposti havaittavia ja ymmärrettäviä. Näytöissä käytetyt symbolit ja niiden merkityssisältö ei ISOBUStyökoneympäristössä ole kaikilta osin vakiintunutta. Niiden havainnolliseksi ja yksiselitteiseksi tekeminen on haasteellista. Symboleille on myös vain rajallisesti tilaa, ja ohjaamon heilunta vaikeuttaa pienten detaljien ja tekstien erottamista. Järjestelmän käyttö vaatii tällöin käyttäjältä uuden oppimista ja muistamista, mikä lisää käyttäjän kognitiivista kuormaa.

Näytössä on usein tarjolla myös informaatiota, jota ei tarvita normaalissa työn suorituksessa. Toisaalta tarvittavaa tietoa on haettava useasta eri näytöstä, joista osa on traktorin kiinteitä näyttölaitteita. Koska käyttäjät, käyttökonteksti ja käyttötavat kuitenkin eroavat toisistaan, olisi hyvä, että käyttäjä voisi valita tarvittavat tiedot näkyviin yhdelle näytölle ja piilottaa muut.

\section{Katsekameramenetelmän arviointi}

Katsekameran ja monikanavavideoinnin yhdistäminen primaaritiedonkeruuseen kuljettajan toiminnasta ohjaamossa on välttämätöntä, jotta voidaan hallita sekä detaljitietoa (visuaalisen huomion tarkka kohdistuminen) että kokonaiskuva työsuorituksesta ja sen kontekstista. Katsekameravideoinnin haasteena on kattaa koehenkilön käyttämä havaintokenttä, sillä kuljettaja tarkkailee työn aikana toistuvasti yli 180 asteen sektoria etuvasemmalta myötäpäivään lähes taaksepäin koneyhdistelmän ajosuuntaan nähden. Näin laajassa havaintosektorissa jää tarkka katseen kohde menetelmän rajoituksista johtuen rekisteröitymättä sektorin äärilaidoilla. Tarkasteltavat käyttöliittymälaitteet ovat kuitenkin aina olleet tarkan katseen rekisteröinnin alueella.

Videomateriaalin läpikäynti koehenkilön haastattelun aikana on erittäin hyödyllistä, sillä se tukee käyttäjän muistikuvia tarkastelluista tilanteista. Haastattelun aikana voidaan myös validoida analyysissä tehdyt oletukset käyttäjän tavoitteista kulloisessakin käyttöliittymän käsittelytilanteessa. 


\section{Johtopäätökset}

ISOBUS-standardi on hyvä lähtökohta valmistajasta riippumattoman, keskenään yhteensopivan traktorityökoneyhdistelmän toimivuudelle. Standardin laatimisessa painopiste on kuitenkin vahvasti ollut teknisen yhteensopivuuden kriteerien luomisessa. Osa tässä hankkeessa tähän mennessä tehdyistä, käytettävyydessä havaituista puutteista juontaa juurensa standardin rajoittuneisuuteen. Osa kehittämiskohteista liittyy kuitenkin perinteisen käyttöliittymäsuunnittelun alaan, ja oman tarkastelunsa ansaitsee myös ISOBUSlaitteiden, -traktoreiden ja -työkoneiden suunnittelun kehittäminen siihen suuntaan, että jälkiasennettavien järjestelmäosien käytettävyys on vähintään samaa tasoa kuin ohjaamoon integroitujen käyttöliittymien.

Tarkasteltua ISOBUS-yhteensopivaa järjestelmää testataan ja kehitetään edelleen keväällä 2012. Tämän tuloksena saadaan lisää suunnittelukriteereitä järjestelmän käytettävyydelle turvallisuuden, tehokkuuden ja käytön miellyttävyyden näkökulmasta. Koska ohjaamossa olevat käyttöliittymän osat kuitenkin ovat vain osa tarkasteltavaa järjestelmää, on jatkossa arvioitava koko järjestelmää samoista näkökulmista.

\section{Kirjallisuus}

Haapala, H., Nurkka, P., Kaustell, K., Mattila, T. \& Suutarinen, J. 2007. Usability in precision agriculture : ecology and agricultural machinery. In: 5th International scientific and practical conference. $5 \mathrm{~s}$.

Kaustell, K.O. \& Mattila, T.E.A. 2008. Capturing the tractor driver's work load using HRV measurement. In: International Conference on Agricultural Engineering, AgEng2008, Conference Proceedings CD. 4 s.

Kaustell, K.O., Mattila, T.E.A. \& Suutarinen, J. 2008. Käyttäjätieto uuden teknologian arvioinnissa ja kehittämisessä. In: Toim. Anneli Hopponen. Maataloustieteen Päivät 2008, 10.-11.1.2008 [: esitelmät ja posterit]. Suomen maataloustieteellisen seuran tiedote 23: s p.

Nielsen, J. 1993. Usability Engineering. Academic Press.

Nurkka, P. 2005. Study in usability evaluation in the field of agricultural engineering. In: (toim.) Coleen Heemskerk and Mari Engvall. Book of Abstracts 5 ECPA - 2 ECPLF. ss. 218-219.

Nurkka, P. 2006. Käyttäjäkeskeisen suunnittelun tarkastelu maatalouskoneen kehityksessä. Taiteen maisterin työ, Taideteollinen korkeakoulu. $97 \mathrm{~s}$.

Nurkka, P. \& Suomi, P. 2006. Käytettävyystutkimus maatalousteknologiassa - Case: kuljettajan tilannetietoisuus Maataloustieteiden päivät 2006. www.smts.fi

SFS-EN 894-4 2010. Koneturvallisuus. Merkinantolaitteiden ja ohjaimien suunnittelun ergonomiset vaatimukset. Osa 4: Merkinantolaitteiden ja ohjaimien sijoittaminen ja järjestely. 